\title{
Experience in Creating Protected Zones Around Nests of Birds of Prey and Black Stork in Ukraine
}

\section{ОПЫТ СОЗДАНИЯ ОХРАННЫХ ЗОН ВОКРУГ ГНЁЗД ХИЩНЫХ ПТИЦ И ЧЁРНОГО АИСТА В УКРАИНЕ}

\author{
Viter S. G.(National nature park "Gomilshansky Lisy", Kharkiv region, Ukraine) \\ Витер С.Г. (Национальный природный парк «Гомольшанские леса», Харьковская \\ область, Украина)
}

\section{Контакт: \\ Станислав Витер Национамьный природный парк "Гомольшанские леса" 61077, Украина, Харьков, пл. Свободы, 4 viter_stanislav@ukr.net}

\author{
Contact: \\ Stanislav Viter \\ Interdepartment \\ laboratory "Biodiversity \\ investigation and \\ conservation \\ development" \\ National Park \\ "Gomilshansky Lisy" \\ Svobody sq., 4, \\ Kharkov, \\ Ukraine, 61077 \\ viter_stanislav@ukr.net
}

Резюме

В статье приводится краткая информация о проекте создания охранных зон вокруг гнёзд хишных птиц и чёрного аиста (Ciconia nigra) в ряле нацпарков Украины в рамках проекта, подцержанного фондом Русффорда в 2017 г. Ааны ссылки на законодательные акты, которые слелали возможной данную работу. Сделаны преАложения по размеру охранных зон вокруг гнёзд разных видов пернатых хищников.

Киючевые смова: хищные птицы, пернатые хищники, охрана гнездовий, зоны особой охраны, особо защитные участки леса, ОЗУЛ, Украина.

Поступима в ремакцию: 22.12.2017 г. Принята к публикации: 30.12.2017 г.

\section{Abstract}

This article concludes a brief information about the project for the creation of protected zones around nests of the raptors and Black Storks (Ciconia nigra) in different national parks in the framework of a project supported by the Rufford Foundation in 2017. There are references to the legislative acts that made possible this work. Proposals on the size of protected zones around nests of different raptors species have been are given. Keywords: birds of prey, raptors, protection of nests, protected zones, especially protective areas of the forest, Ukraine.

Received: 22/12/2017. Accepted: 30/12/2017.

DOI: $10.19074 / 1814-8654-2017-35-68-73$

В 2015-2016 годах в Украине, в рамках процесса Евроинтеграции страны, были приняты важные законодательные акты, направленные на охрану мест гнездования редких видов птиц, а именно - чёрного аиста (Ciconia nigra), сов (Strigidae) и прелставителей Авух отрядов Аневных хишных птиц (Accipitriformes, Falconiformes).

Верховная Раха Украины приняла 2 законодательных акта, а именно: "Закон тишины", согласно которому во всех лесах страны запрешено проведение любых лесохозяйственных мероприятий, использование аудиотехники, усилителей звука и пр. в период с 1 апреля по 15 июня (Закон Украины..., 2015); второй акт - Аополнения к санитарным правилам в лесах Украины, согласно которым «Запрешается осушествление мероприятий по улучшению санитарного состояния лесов вокруг мест гнездования хишных птиц, занесённых в Красную книгу Украины (радиусом 500 м), и чёрного аиста (рахиусом 1000 м), токов глухарей, тетеревов (радиусом 300 м)" (Постановление..., 2016; Санитарные правила..., 2016).

$\triangle$ ополнительно были приняты некоторые законодательные акты, обязываюшие национальные природные парки (НПП)
In 2015-2016 in Ukraine, as part of the European integration of the country, important acts of legislation were passed to protect breeding grounds of rare bird species, namely Black Stork (Ciconia nigra), owls (Strigidae) and birds of prey (Accipitriformes, Falconiformes).

The Verkhovna Rada of Ukraine adopted the "Law of Silence" that prohibits carrying out any forestry practice, use of audio equipment, audio amplifiers, etc. in all forests of the country during the period of April 1 to June 15 (The Law of Ukraine..., 2015). The second act of legislation is supplementary sanitary rules in the forests of Ukraine, which "prohibit carrying out activities to improve the sanitary condition of forests around the breeding places of birds of prey, listed in the Red Data Book of Ukraine (500 m radius), and Black Stork (1000 m radius), lekking of Western Capercaillie, Black Grouse (300 m radius)" (Resolution..., 2016; Sanitary rules..., 2016). Additionally an Act of legislation was adopted obliging National Parks (NP) to create protective zones around nests, in particular, the order of the Ministry of Ecology and Natural Resources of Ukraine No. 557 dated 29/12/2016 (Order..., 2016). This order establishes the ra- 
создавать охранные зоны вокруг гнёзд, в частности, приказ Министерства экологии и природных ресурсов Украины № 557 от 29.12.2016 (Приказ..., 2016). Этим приказом устанавливается рахиус бусерной зоны вокруг гнёзА мия Аневных хишных птиц, занесённых в Красную книгу Украины, - 500 м, Аля сов - 100 м. Важность этого Аокумента закиючается в том, что, благоАаря нему, теперь возможен официаиьный вывод из лесопользования мест гнездования хишных птиц, хотя бы на территориях НПП. На большей части НПП Украины (анамог в Аругих странах - национальный парк) $\Delta$ о $50 \%$ и более территорий приходится на хозяйственную зону, пребываюшую в управлении не амминистраций национальных парков, а Аругих землепользователей, чаше всего - лесхозов. В большинстве НПП страны режим лесопользования мало отличается от такового в обычных лесхозах. И $\Delta$ последнего времени места гнездования хищных птиц уничтожаяись в ходе рубок.

В 2016 году начаися сбор Аанных о наиичии краснокнижных виАОв хишных птиц в НПП Украины. Большая часть НПП подала информацию о наиичии таких видов и были приняты соответствуюшие приказы о созАании охранных зон. Постепенно начаии подкиючаться и некоторые лесхозы, в которых важной составляюшей деятельности является и охрана природы: Государственное предприятие "Тетеревское лесное хозяйство" и ГП «Макаровское лесное хозяйство" (оба Киевская область). В Харьковской области ГП «Купянское лесное хозяйство», также подаио материаиы на создание охранных зон, в том числе и по видам хишных птиц, не вкиюченным в "Красную книгу Украины" (Червона книга ..., 2009).

В настояшее время - к Аекабрю 2017 года, количество охранных зон в местах обитания реАких вицов птиц в Украине превысияо 1000. Сушественная часть этих зон была вылелена в результате успешного проведения проекта "Создание охраняемых dius of the buffer zone around the nests for diurnal birds of prey, listed in the Red Data Book of Ukraine - $500 \mathrm{~m}$, for owls $-100 \mathrm{~m}$.

In 2016 the data collection was launched on the presence of birds of prey listed in the Red Data Book in the Ukrainian National Parks. Most of NPs provided information on the presence of such species and the relevant orders were adopted for establishment of protective zones. Gradually, some forestry enterprises, an important component of which is environmental protection, got involved. In the Kharkiv region SE "Kupyanskoe forestry" also submitted files for the establishment of protective zones, including by birds of prey species, not listed in the Red Data Book of Ukraine (2009).

By December 2017 the number of protective zones in the habitats of rare bird species in Ukraine exceeded 1000. A considerable part of these zones was selected as a result of the successful implementation of the project "To establish protective zones around the Raptors nests - the way to preserve both key Raptors population and biodiversity generally", supported by Rufford Small Grants for Nature Conservation (Viter, 2017a).

The territories of such national nature parks as "Gomolshanskie Lesa", "Dvurechansky", "Slobozhansky" (all three in the Kharkov region) and "Goloseevsky" (in the Kiev region), forest park area of the cities of Kharkov and Kiev, and 3 forestry enterprises - SE "Teterevskoe forestry" (Kiev region), SE "Kupyanskoe forestry" and "Oktyabrsky forestry" (both in the Kharkiv region) were chosen for the project implementation.

The research was conducted in March - July 2017. Based on the results of the research conducted, materials were submitted for the establishment of 348 protective zones with a total area of 18030 hectares, more than half of which gained status of protective zones, while the rest are under consideration.
Обследование лесных территорий с воздуха с помощью квадрокоптера. Фото С. Витера.

Forests survey from the air the using of quadrocopter. Photo by S. Viter.

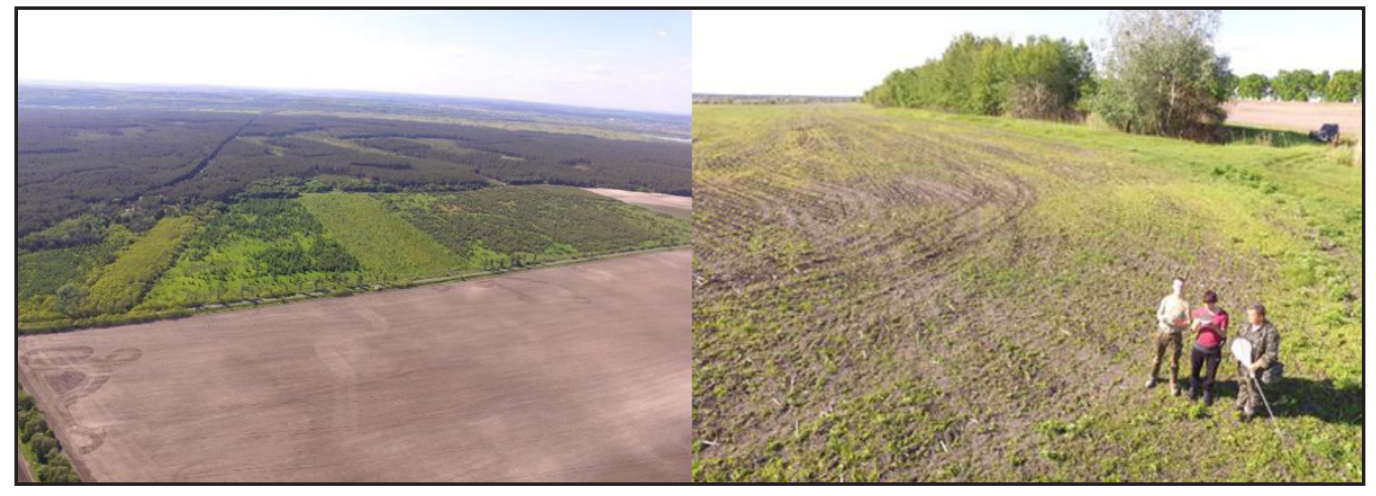


зон вокруг гнёзА хищных птиц - способ сохранения, как киючевых популяций хищников, так и биоразнообразия в целом" (То establish a protected zones around the Raptors nests - the way to preserve both key Raptors population and biodiversity generally), полдержанного Инициативой мамых грантов фонда Русрсрорла (Rufford Small Grants for Nature Conservation) (Viter, 2017a).

Наше внимание было сосредоточено на обследовании хозяйственных зон ряла национальных природных парков с целью поиска гнёзА редких видов пернатых хишников и чёрного аиста. Аалее инсормацию о наиичии гнёзд чёрного аиста, хишных птиц и сов (не только краснокнижных виАов) $А$ водихи Ао ведома ацминистраций парков. На основании отчётов о выполненных работах, в обследованных нацпарках были выделены лесные квартамы и вылелы, в прелелах которых было запрешено проведение сплошных (в т.ч. постепенных и узколесосечных) рубок леса, а в некоторых случаях (места гнездования подорликов Aquila pomarina, Aquila clanga) был введён запрет на проведение выборочных рубок леса. Соответственно были внесены коррективы во временной режим использования экомогических троп и туристических маршрутов, а часть маршрутов была изменена.

Основными Аокументами, регулируюшими правовой статус охранных зон, являются приказы Аиректоров национаиьных природных парков и лесхозов о создании охранных зон и режиме использования таких территорий, проекты организаций территорий, а также материаиы лесоустройства.

мия реаиизации проекта были выбраны территории национамьных природных парков "Гомольшанские леса", "Авуречанский", "Слобожанский" (все три - Харьковская область) и "Голосеевский» (Киевская область), лесопарковая зона городов Харьков и Киев, а также 3 лесхоза - ГП «Тетеревское лесное хозяйство" (Киевская область), ГП "Купянское лесное хозяйство" и ОктябрьСкий лесхоз (оба - Харьковская область).

Исследования проводили в марте - июле 2017 года. По результатам исследования поданы материамы на создание 348 охранных зон обшей пмощамью 18030 га, из которых более половины получили статус охранных зон, а остаяьные пребывают на сталии рассмотрения.

Особенно хотелось бы подчеркнуть усилия Национаьного природного парка «Гомольшанские леса", а из лесхозов - ГП «Тетеревское лесное хозяйство». В некоторых случаях охранные зоны быми созданы решениями

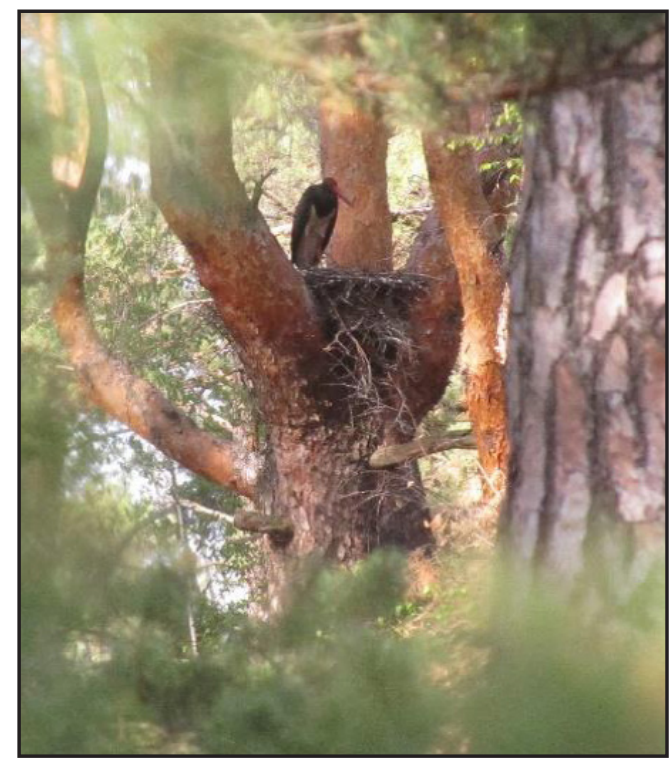

Гнездо чёрного аиста (Ciconia nigra) в Полесье (Киевская область, Украина). Фото из: Viter, $2017 \mathrm{~b}$.

Nest of the Black Stork (Ciconia nigra) in the Polesie forests, Kyiv region of Ukraine. Photo from S. Viter, $2017 \mathrm{~b}$.

The largest number of protected zones was created around the nests of the Common Buzzard (Buteo buteo) - 240, Tawny Owl (Strix aluco) - 19 and Booted Eagle (Hieraaetus pennatus) - 13, and also: Long-Legged Buzzard (Buteo rufinus) - 10, Hobby (Falco subbuteo) - 10, Eurasian Sparrowhawk (Accipiter nisus) - 9, Black Stork (Ciconia nigra) - 8, Short-Toed Eagle (Circaetus gallicus) - 7, Goshawk (Accipiter gentilis) - 7, Black Kite (Milvus migrans) - 6, Honey Buzzard (Pernis apivorus) - 5, Eastern Imperial Eagle (Aquila heliaca) - 4, Eurasian Crane (Grus grus) - 4, White-Tailed Eagle (Haliaeetus albicilla) - 3, Lesser Spotted Eagle - 3, Hen Harrier (Circus cyaneus) - 2, Greater Spotted Eagle - 1 (Viter, 2017b).

For the further success of the breeding grounds territorial protection idea for rare bird species the basic requirement is differentiation of the protective zones sizes. It is required to refrain from dividing zones into two categories - with radius of 100 and $500 \mathrm{~m}$ (ref. Order..., 2016).

We recommend the following gradation: - small falcons (Kestrel Falco tinnunculus, Hobby, Red-Footed Falcon F. vespertinus), Tawny Owl, Eurasian Pygmy Owl (Glaucidium passerinum) and Boreal Owl (Aegolius funereus): $100 \mathrm{~m}$;

- Common Buzzard, Booted Eagle, LongLegged Buzzard, Honey Buzzard, Black Kite, Red Kite (Milvus milvus), Saker Falcon (Falco 
местных органов власти, преимушественно местными советами. Особенно следует отметить работу Киевского городского совета.

Наибольшее количество охранных зон создано вокруг гнёзд обыкновенного канюка (Buteo buteo) - 240, а также серой неясыти (Strix aluco) - 19 и орла-карлика (Hieraaetus pennatus) - 13. По Аругим видам итоги таковы: курганник (Buteo rufinus) - 10, чеглок (Falco subbuteo) - 10, перепелятник (Accipiter nisus) - 9, чёрный аист (Ciconia nigra) -8 , змееял (Circaetus gallicus) -7 , тетеревятник (Accipiter gentilis) - 7, чёрный коршун (Milvus migrans) - 6 , осоеА (Pernis apivorus) - 5, могильник (Aquila heliaca) - 4, орлан-белохвост (Haliaeetus albicilla) - 3, мамый подорлик - 3, большой подорлик - 1, а также: серый журавль (Grus grus) - 4, полевой лунь (Circus cyaneus) - 2 (лесные поляны и небольшие болота посреди леса, учтённые в лесном фонде) (Viter, 2017b).

Разработаны и поданы на рассмотрение в компетентные органы власти научные обоснования на создание 6 заказников местного значения в Харьковской области обшей плошанью 446,159 га

При осушествлении таких проектов возникает рял проблем, прежде всего связанных с выбором территорий имплементации проекта, нормативно-правовой базой, сохранением гнёзд в условиях их известности большому числу мюАей.

Например, следует ки ограничиваться внутренними приказами по предприятиям или же добиваться внесения информации в устанавливаюшую документацию (проекты организаций территорий, проекты месоу-

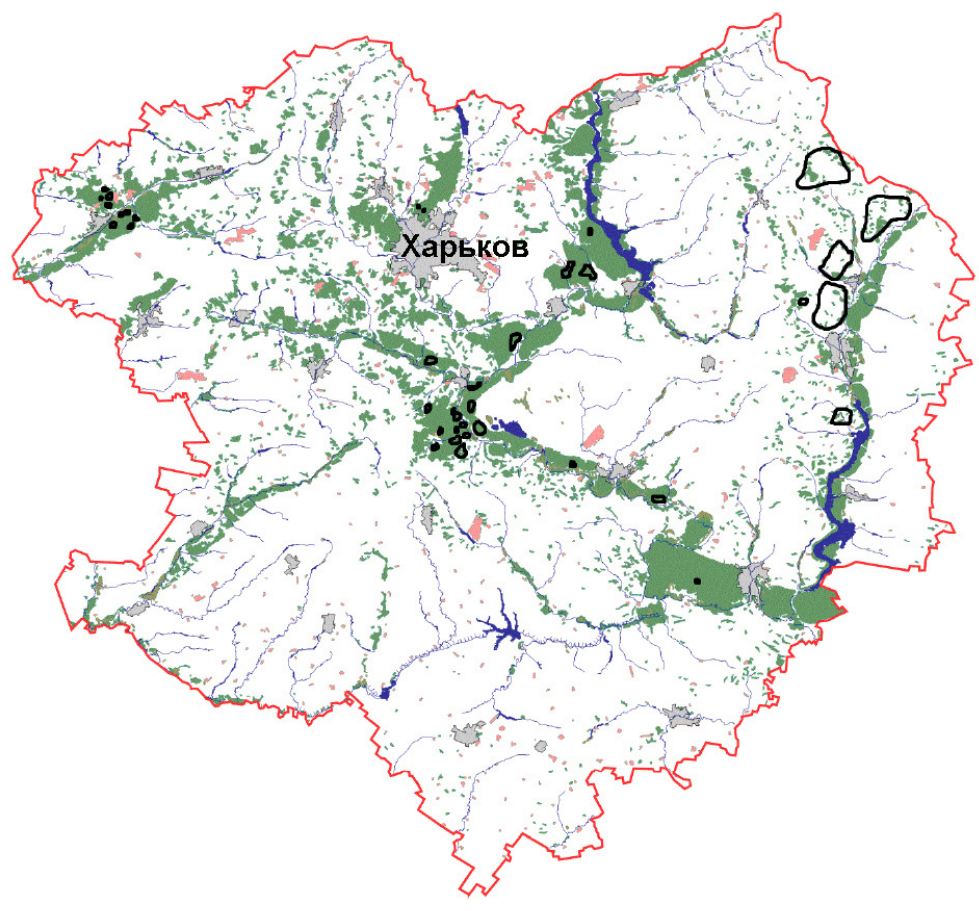

cherrug), Peregrine Falcon (Falco peregrinus), Ural Owl (Strix uralensis): forest edges or watershed forests: $300 \mathrm{~m}$; in the depths of upland oak forests near the slopes of the hills, as well as along the forested slopes $-200 \mathrm{~m}$;

- Eastern Imperial Eagle, Lesser Spotted Eagle, Short-Toed Eagle, Eagle Owl (Bubo bubo), Great Grey Owl (Strix nebulosa), Black Stork: at the edges and in small (less than 50 hectares) forests $-500 \mathrm{~m}$, in the depths of the forest $-400 \mathrm{~m}$;

- White-Tailed Eagle - 700 m;

- Golden Eagle (Aquila chrysaetos), Greater Spotted Eagle - 1000 m.

Our research made it possible to find a number of forest biotopes (formations), most significant as breeding grounds of rare bird species, incl. birds of prey. Such biotopes include:

- forests and forest-steppes of the age of 100 and older;

- mountain forest-steppe oak-groves from the age of 80 (seed) and 120 (coppice);

- ravine oak forests (forest-steppe, steppe) of the age of 80 ;

- floodplain oak forests of the age of 70;

- alder swamp forests of the age of 50;

- mountain forests of Crimea (hornbeam and rock oak forests, pubescent oak forests, pine forests, shibliak and maquis, including juniperic forests, mountain pine forests, beech forests);

- slope forests (valley side) in large river valleys (water intensity from $25 \mathrm{~m}^{3} / \mathrm{sec}$.), of the age of 70 (with oaks and hornbeams predominantly) and of the age of 40 (poplars, birches);

- all types of floodplain forests (of all ages) in the steppe zone;

- forest islets on upland and transitional bogs and on their edge (50-meter-long premarginal zone), of the age of 70 ;

- coniferous forest areas of the age of 130;

- oak-pine forests of the age of 120 ;

- leaf bearing and mixed forests on water-logged lowlands in forest-steppe and steppe zones;

- beech forests of Carpathians and Podolia of the age of 100 , beech-spruce forests and spruce forests of Carpathians of the age of 80 .

For these forest types we recommend to stop clear (all types), border and gradual clear felling.

Охранные зоны вокруг гнёзд хишных птиц в Харьковской области Украины.

Protected zones around the Raptors ' nests in Kharkiv region, Ukraine. 
стройства, пр.)? Какие национаиьные парки и лесхозы выбрать мля осушествления поАобных проектов? Каковы риски разглашения информации о гнёздах редких видов?

Отвечая на первый вопрос, хотим заметить, что лучшим вариантом является внесение базы охранных зон в общие установочные Аокументы - проекты организации территорий. Выбор территорий мия осушествления проекта слелан по принципу нацёжности организации-сотрудника: заинтересованность амминистраций в осушествлении подобных природоохранных инициатив, надёжность в пиане нераспространения точных Аанных о расположении гнёзд, способность амминистраций национаиьных парков осушествлять

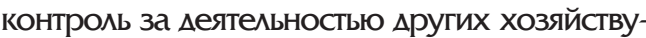
ющих субъектов в пределах территории национаиьного парка.

В случае лесхозов важным фрактором является актуальность создания охранной зоны на фоне возможного широкого разглашения инсормации о точном месте расположения гнезда редкой (часто - коммерчески ценной) птицы. Например, есть гнездо орла некоего вида или крупного сокола. На данном участке леса в течение ближайших 10-15 мет не запланировано проведение сплошных рубок (единственного вида рубок, который может полностью уничтожить гнезАовой участок птицы). В Аанном случае куда важнее сохранить информацию в тайне, нежели создавать охранную зону и привлекать внимание как землепользователей, так и прочих чиновников, а следовательно - вести к разглашению важной инсоомации. При заинтересованности ахминистрации лесхоза важно, прежле всего, обеспечить создание охранных зон вокруг гнёзА реАких виАов, но не преАставляюших коммерческую ценность и устойчивых к фактору периодического беспокойства. Важно также отдавать предпочтение участкам, расположенным в наиthe Raptors` nests in Kyiv region, Ukraine.

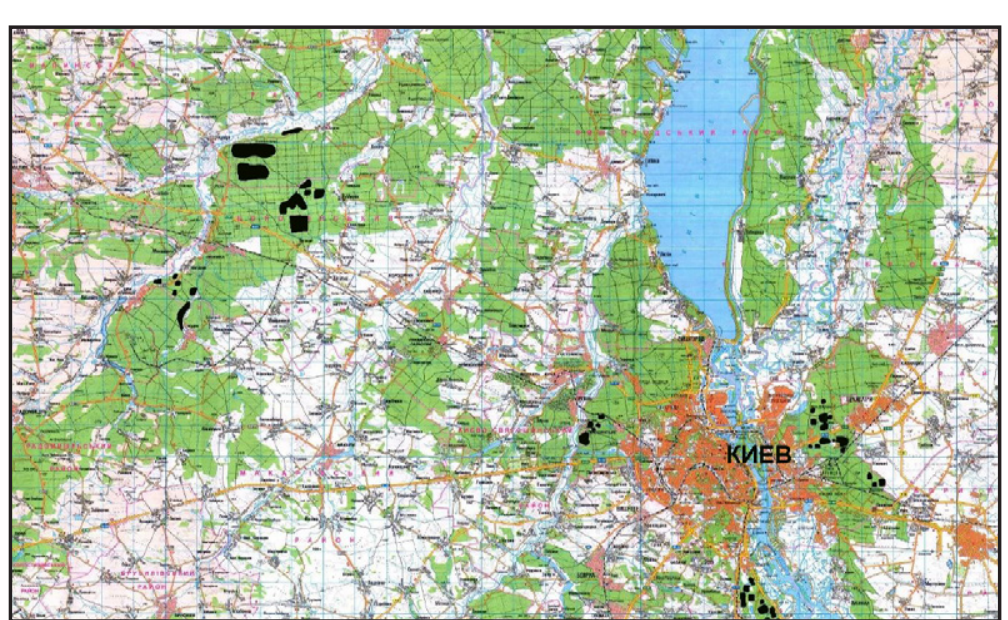

более редких лесных формациях, а также нал которыми нависла реацьная угроза вырубки (участок внесён в планы рубок в течение ближайших 1-3 лет и, особенно, отведённых под вырубку).

мяя дамьнейшего успеха идеи территориамьной охраны мест гнездования редких виАов птиц важным условием является Аифференцирование размеров охранных зон. Необходимо отказаться от деления зон на 2 категории - радиусом 100 и 500 м (см. Приказ..., 2016).

Рекомендуем следуюшие градации:

- мелкие сокола (пустельга Falco tinnunculus, чеглок, кобчик $F$. vespertinus), серая неясыть, сычи (воробьиный Glaucidium passerinum и мохноногий Aegolius funereus): 100 м;

- обыкновенный канюк, орёл-карлик, курганник, осоед, чёрный коршун (равно как и красный коршун Milvus milvus), крупные соколы (балобан Falco cherrug, сапсан Falco peregrinus), мииннохвостая неясыть (Strix uralensis): опушки или плакоры: рахиус 300 м; в глубине нагорных дубрав вблизи яров, а также по скионам облесённых яров - 200 м;

- орёл-могильник, малый подорлик, змееял, фрилин (Вubo bubo), бородатая неясыть (Strix nebulosa), чёрный аист: у опушек и в небольших (менее 50 га) лесах - 500 м, в глубине леса - 400 м;

- орлан-белохвост - 700 м;

- беркут (Aquila chrysaetos), большой подорлик - 1000 м.

Наши исследования позволили выделить ряд лесных биотопов (формаций), наиболее значимых как места гнездования редких виАОв птиц, в т.ч. и хишных. К таким биотопам можно отнести:

- лесные и лесостепные боры 100 лет и старше;

- нагорные лесостепные дубравы возрастом от 80 лет (семенные) и 120 лет (порослевые);

- байрачные дубравы (лесостепь, степь) возрастом от 80 лет;

- пойменные дубравы возрастом от 70 лет;

- ольховые заболоченные леса возрастом от 50 мет;

- горные леса Крыма (грабово-скальнодубовые, пушистодубровые, сосновые, шибляки и маквис, в т.ч. можжевеловые леса, леса из горной сосны, буковые леса);

- склоновые леса (по коренным берегам) в Аолинах больших рек (водоёмкостью от $25 \mathrm{~m}^{3} /$ сек.), возрастом от 70 лет (с преоблаханием дуба и граба) и 40 лет (тополя, берёзы); 
Гнездовой участок (теперь охранная зона) и гнездо орлана-белохвоста (Haliaeetus albicilla) в Изюмском районе Харьковской области Украины.

Фото из: Viter, $2017 b$.

Nest-site (now - one of the protected zones) and nest of the WhiteTailed Eagle (Haliaeetus albicilla) in Izyum district, Kharkiv region of Ukraine. Photo from S. Viter, 2017b.

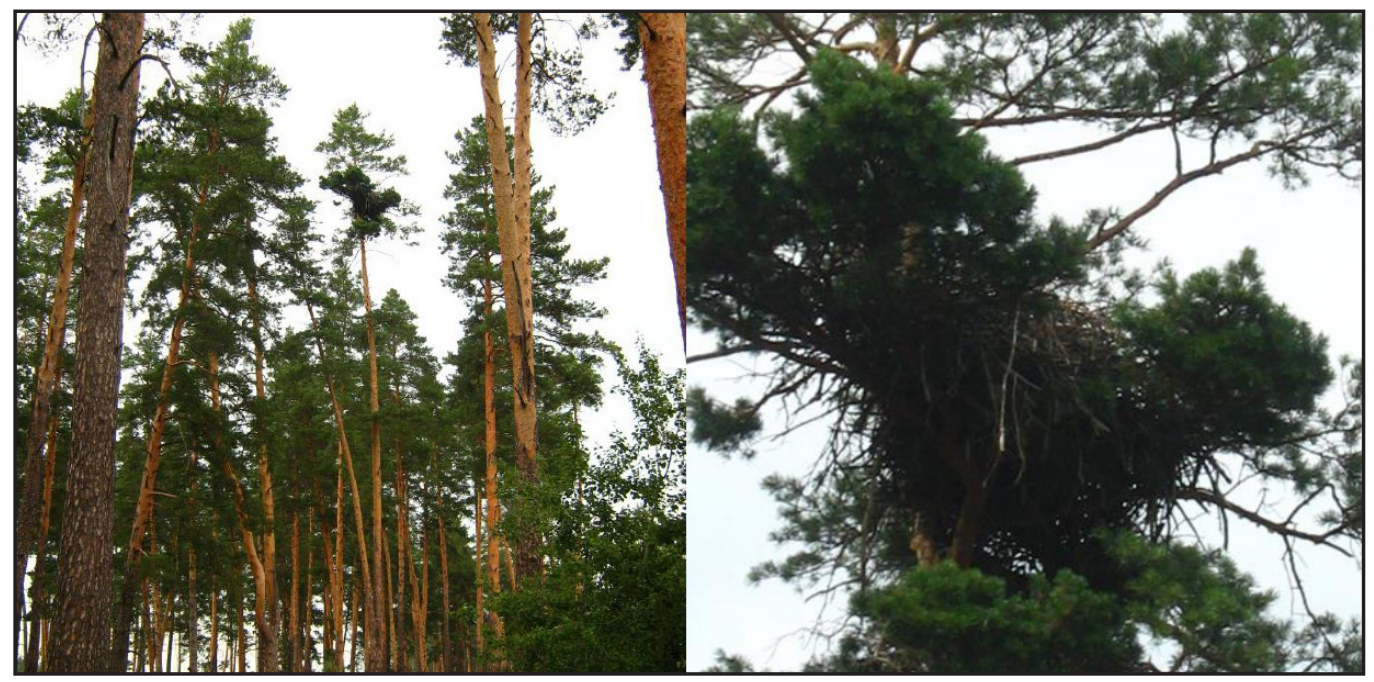

- все типы пойменных лесов (независимо от возраста) в степной зоне;

- островки леса на верховых и перехолных болотах и по их окраине (50-метровая приопушечная зона), возрастом от 70 лет;

- полесские боры возрастом от 130 лет;

- дубово-сосновые леса, возрастом от 120 лет;

- лиственные и смешанные леса на боровых блюдцах (заболоченных понижениях) в лесостепной и степной зоне;

- буковые леса Карпат и Подолья возрастом от 100 лет, буково-еловые и еловые леса Карпат возрастом от 80 лет.

Аля этих типов лесов рекомендуем полностью отказаться от проведения сплошных (все типы), узколесосечных и постепенных сплошных рубок.

\section{Благодарности}

Автор выражает благодарность фонду Русрсрорда (Rufford Foundation), благодаря подцержке которого стало возможным проведение этого исследования и его имплементация, Киевскому эколого-культурному центру и кично В.Е. Борейко за помощь в придании юридического статуса охранным зонам, сотрудникам Национамьных природных парков «Гомольшанские леса", "Слобожанский" и "Авуречанский", а также сотрудникам ГП «Тетеревское лесное хозяйство" за помошь в проведении полевых работ.

\section{Митература}

Закон Украины "О внесении изменений в некоторые законодательные акты Украины по охране животного мира", № 322-VIII, 9 апреля 2015 г. [The Law of Ukraine "On Amendments to Certain Legislative Acts of Ukraine for the Protection of Fauna", No. 322-VIII, April 9, 2015.]. URL: http://zakon2.rada.gov.ua/laws/show/322-19 Аата обрашения: 20.12.2017 г.
Постановление Кабинета Министров Украины "О внесении изменений в постановления Кабинета Министров Украины от 27 июля 1995 № 555 и от 12 мая 2007 № 724 " № 756 , 26 октября 2016 г. [Resolution of the Cabinet of Ministers of Ukraine "On Amendments to Resolutions of the Cabinet of Ministers of Ukraine No. 555 of July 27, 1995 and No. 724 of May 12, 2007" No. 756, October 26, 2016.]. URL: http://zakon2.rada.gov.ua/laws/show/7562016-\%D0\%BF Аата обрашения: 20.12.2017 г.

Приказ Министерства экологии и природных ресурсов Украины "О дополнительных мерах по сохранению редких и исчезающих виАОв животных и растений” от 29.12.2016 № 557 [Order of the Ministry of Ecology and Natural Resources of Ukraine "On Additional Measures for the Conservation of Rare and Endangered Species of Animals and Plants" of December 29, 2016 No. 557]. URL: http://old.menr.gov. ua/docs/normakty/2016/nakaz_557_29122016.pdf Аата обрашения: 20.12.2017 г.

Санитарные правияа в лесах Украины (в реАакции постановления Кабинета Министров Украины от 26 октября 2016 № 756) [Sanitary rules in the forests of Ukraine (as amended by the Resolution of the Cabinet of Ministers of Ukraine of October 26, 2016, No. 756)]. URL: http://zakon2.rada.gov.ua/laws/show/555-95-\%D0\%BF Аата обрашения: 20.12.2017 г.

Червона книга України. Тваринний світ/ за реА. І.А. Акімова. Київ: Глобалконсаитинг, 2009. 600 c. [Red Data Book of Ukraine. Animals / ed. I.A. Akimov. Kiev, 2009: 1-600. (in Ukrainian)]. URL: http://redbook-ua.org/files/Red_book_animals_2009.zip Аата обрашения: 20.09.2016.

Viter $S$. To Establish a Protected Zones around the Raptors Nests - The Way to Preserve both Key Raptors Populations and Biodiversity Generally. - The Rufford Foundation. 2017a. URL: https://www.rufford.org/projects/stanislav_viter $\triangle$ ата обрашения: 20.12.2017

Viter S. Detailed final report: To Establish a Protected Zones around the Raptors Nests - The Way to Preserve both Key Raptors Populations and Biodiversity Generally. - The Rufford Foundation. 2017b. URL: https://www.rufford.org/ files/21317-2\%20Detailed\%20Final\%20Report. pdf Аата обрашения: 20.12.2017. 